Review Article

\title{
A SCIENTIFIC APPROACH FOR NAHWU LEARNING
}

\author{
Siti Zaenab
}

\begin{abstract}
The purpose of this study was to determine the development of scientific-based Nahwu learning modules at SMA Darul Ulum 3 Jombang. This research uses the research and development method of the Plomp model. The research targets consisted of the experimental class and the control class. The experimental class is class X IPS2 SMA Darul Ulum 3 Jombang in the 2017/2018 academic year, while the control class is class X MIPA 1 SMA Darul Ulum 3 Jombang in the 2017/2018 academic year. The results of the feasibility test show that the instrument is valid for research. with very good achievement scores, namely: material experts $82.5 \%$, and expert practitioners $83.7 \%$. The results showed that the Nahwu learning module using a scientific approach obtained a significance value $=$ 0.200 and $0.062>0.05$ during the normality test between the control class and the treatment class. As for the results of the homogeneity test, the significance value $=0.752$ and $0.569>0.05$, and the t-test found that the Sig. (2-tailed) for the posttest of 0.030 . Sig. (2-tailed) $0.030<5 \%$ then the result of $t$ test is $\mathrm{HO}$ is rejected. So, there are differences in student learning outcomes using the nahwu learning module using a scientific approach with student learning outcomes using textbooks..
\end{abstract}

Keywords: module, Nahwu learning, Scientific.

\section{PENDEKATAN SAINTIFIK DALAM PEMBELAJARAN NAHWU}

\begin{abstract}
Abstrak
Tujuan penelitian ini adalah untuk mengetahui pengembangan modul pembelajaran Nahwu berbasis saintifik di SMA Darul Ulum 3 Jombang. Penelitian ini menggunakan metode penelitian dan pengembangan model Plomp. Sasaran penelitian terdiri atas sasaran kelas eksperimen dan kelas kontrol. Adapun kelas eksperimen adalah siswa kelas X IPS2 SMA Darul Ulum 3 Jombang Tahun Pelajaran 2017/ 2018, sedangkan kelas control adalah siswa kelas X MIPA 1 SMA Darul Ulum 3 Jombang Tahun Pelajaran 2017/ 2018. Hasil uji coba kelayakan menunjukan bahwa instrumen valid digunakan untuk penelitian dengan nilai pencapaian sangat baik yakni: ahli materi 82, $5 \%$, dan ahli praktisi 83,7 \%. Hasil penelitian menunjukan bahwa modul pembelajaran Nahwu dengan menggunakan pendekatan saintifik didapat nilai signifikansi $=0,200$ dan $0,062>0,05$ pada saat uji normalitas antara kelas kontrol dan kelas perlakuan. Sedangkan untuk hasil dari uji homogenitas didapat nilai signifikansi $=0,752$ dan $0,569>0,05$, dan pada uji-t didapatkan bahwa nilai Sig. (2tailed) untuk pascates sebesar 0,030. Sig. (2-tailed) $0,030<5 \%$ maka hasil uji t adalah $\mathrm{H}_{0}$ ditolak. Jadi, terdapat perbedaan hasil belajar siswa yang menggunakan modul pembelajaran nahwu dengan menggunakan Pendekatan saintifik dengan hasil belajar siswa yang menggunakan buku teks.
\end{abstract}

Kata kunci: modul, pembelajaran Nahwu, Saintifik 


\section{Pendahuluan}

Pembelajaran Pendidikan Agama Islam (PAI) pada jenjang pendidikan menengah atas dibawah naungan pesantren, lima aspeknya (Al-Qur an Hadits, Aqidah, Akhlak, Fiqih, Tarikh Islam) dilaksanakan secara terpisah-pisah. Salah satu sumber belajar yang digunakan adalah kitab-kitab klasik berbahasa Arab yang membutuhkan pemahaman kaidah-kaidah bahasa Arab, dalam hal ini adalah ilmu Nahwu. Ilmu Nahwu merupakan salah satu mata pelajaran yang harus dipelajari oleh peserta didik di tingkat menengah atas yang berlatar belakang pondok pesantren. Adapun problematika yang muncul adalah kurang menariknya pembelajaran tersebut dikarenakan strategi pembelajarannya, baik metode maupun media pembelajarannya masih banyak sistem menghafal, sehingga yang terjadi adalah antusiasme siswa berkurang yang disebabkan juga latar belakang pendidikan dasar mereka yang berbeda-beda.

Pengembangan bahan ajar mata pelajaran Nahwu pada jenjang pendidikan menengah ke dalam bentuk modul di sekolah masih jarang dilakukan para guru Nahwu. Karena keterbatasan kualifikasi, kesempatan, motivasi, minat, dan kendala-kendala yang lainnya, para guru sangat berat untuk menyusun modul pembelajaran. Modul pembelajaran merupakan satuan program belajar mengajar yang terkecil, yang dipelajari oleh siswa sendiri secara perseorangan atau diajarkan oleh siswa kepada dirinya sendiri self-instructional. ${ }^{1}$.

Modul merupakan bahan ajar cetak yang dirancang untuk dapat dipelajari secara mandiri oleh peserta pembelajaran. Modul disebut juga media untuk belajar mandiri karena di dalamnya telah dilengkapi petunjuk untuk belajar sendiri. ${ }^{2}$ Modul adalah bahan ajar yang disusun secara sistematis dan menarik yang mencakup isi materi, metode dan evaluasi yang dapat digunakan secara mandiri untuk mencapai kompetensi yang diharapkan. Selain itu, modul memiliki daya informasi yang cukup kuat. Unsur asosiasi, struktur, dan urutan bahan pelajaran terbentuk sedemikian rupa sehingga siswa secara spontan mempelajarinya. Modul banyak memberikan kesempatan kepada siswa untuk berbuat aktif, sehingga membuka kesempatan kepada siswa untuk maju berkelanjutan menurut kemampuannya masing-masing. ${ }^{3}$

Seiring diberlakukannya kurikulum tahun 2013, sekolah-sekolah disibukkan dengan persiapan-persiapan peningkatan kompetensi pendidiknya dengan mengikuti pelatihan dan workshop di tingkat sekolah maupun di tingkat daerah, tetapi tidak dipersiapkan pembuatan bahan ajarnya. Dengan melihat fenomena seperti itu, penulis ingin mengembangkan bahan ajar

\footnotetext{
${ }^{1}$ W. S. Winkel, Psikologi Pembelajaran. (Yogyakarta: Media Abadi, 2009), 472

${ }^{2}$ Direktorat Jendral Pengembangan Mutu Pendidikan dan Tenaga Pendidikan, Penulisan Modul, (Jakarta: Departemen Pendidikan Nasional, 2008), 3

${ }^{3}$ Ilham Anwar, Pengembangan Bahan Ajar. (Bandung: Direktori UPI, 2010), 23
} 
mata pelajaran Nahwu kelas $\mathrm{X}$ semester gasal ke dalam bentuk modul pembelajaran dengan menggunakan pendekatan saintifik.

Pendekatan saintifik berkaitan erat dengan metode saintifik (ilmiah) yang melibatkan kegiatan pengamatan atau observasi yang dibutuhkan untuk perumusan hipotesis atau mengumpulkan data. Metode ilmiah pada umumnya dilandasi dengan pemaparan data yang diperoleh melalui pengamatan atau percobaan, oleh sebab itu kegiatan percobaan dapat diganti dengan kegiatan memperoleh informasi dari berbagai sumber. ${ }^{4}$ Pada penelitian dan pengembangan ini, penulis akan mengembangkan modul pembelajaran Nahwu kelas X di SMA Darul Ulum 3 Jombang dengan menggunakan pendekatan saintifik dengan harapan bisa memotivasi peserta didik dan memudahkan mereka dalam mempelajari ilmu Nahwu sekaligus memperkuat pemahaman mereka terhadap kitab-kitab klasik berbahasa Arab yang digunakan dalam mendukung proses pembelajaran lima aspek pembelajaran Pendidikan Agama Islam (PAI).

\section{Metode Penelitian}

Penelitian ini adalah penelitian pengembangan (research and development). Penelitian dan pengembangan merupakan proses/metode yang digunakan untuk memvalidasi dan mengembangkan produk. Memvalidasi produk, berarti produk itu telah ada, dan peneliti hanya menguji efektifitas atau validitas produk tersebut. Mengembangkan produk dalam arti yang luas dapat berupa memperbaharui produk yang telah ada (sehingga menjadi lebih praktis, efektif, efisien) atau menciptakan produk baru (yang sebelumnya belum pernah ada). ${ }^{5}$ Model penelitian dan pengembangan yang digunakan dalam penelitian ini adalah penelitian Pengembangan Model Plomp yang menempuh lima fase: a) Fase Investigasi (Preliminary Investigation); b) Fase Desain (Design); c) Fase Realisasi/Konstruksi (Realization/Construction); d) Fase Tes, Evaluasi, dan Revisi (Test, Evaluation, and Revision); e) Fase Implementasi (Implementation).

Teknik pengumpulan data dan pengembangan meliputi beberapa tahap. Pertama, lembar validasi. Tahap pertama ini merupakan rangkaian proses: a) Menyusun format validasi untuk seluruh instrumen (lembar validasi,lembar observasi, angket, dan tes hasil belajar) dengan empat komponen: yaitu (1) tujuan melakukan validasi, (2) petunjuk, (3) aspek yang dinilai (kelayakan instrumen ditinjau dari petunjuk penggunaan instrument, isi dan tujuan, penggunaan bahasa), (4) penilaian secara umum (hasil). b) Memberikan seluruh instrumen

\footnotetext{
${ }^{4}$ Ridwan Abdullah Sani, Pembelajaran Saintifik Untuk Implementasi Kurikulum 3013,(Jakarta: Bumi
} Aksara, 2005), 51.

2016), 28

${ }^{5}$ Sugiyono, Metode Penelitian \& Pengembangan Research and Development (Bandung: Alfabeta, 
penelitian dan format validasi pada pakar dan praktisi, yaitu dengan cara melakukan revisi berdasarkan masukan dari para pakar dan praktisi. ${ }^{6}$ c) kuesioner respons siswa terhadap komponen dan kegiatan pembelajaran. Instrumen ini digunakan untuk memperoleh data mengenai pendapat atau komentar siswa terhadap komponen dan kegiatan pembelajaran yang meliputi materi pelajaran, kegiatan pembelajaran, keterbacaan bahasa dan penampilan buku (modul pembelajaran). Hasil kuesioner respons siswa juga akan digunakan dalam menemukan kekurangan dan kelebihan modul pembelajaran nahwu. Teknik analisis data yang digunakan untuk menganalisis data hasil penilaian kelayakan bahan ajar (modul pembelajaran) dan keterbacaan bahan ajar menggunakan perhitungan rata-rata. Hasil perhitungan rata-rata dideskripsikan di Bab IV tentang hasil. Rumus menghitung nilai rata-rata adalah sebagai berikut

$$
\begin{aligned}
& \text { Keterangan: }
\end{aligned}
$$

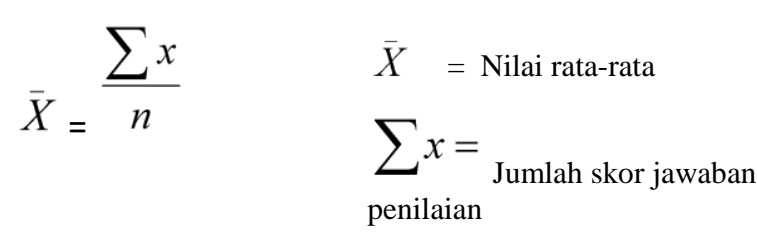

$$
\begin{aligned}
& \mathrm{n} \quad=\text { Jumlah sampel }
\end{aligned}
$$

Untuk memperkuat data hasil penilaian kelayakan, dikembangkan jenjang kualifikasi kriteria kelayakan. Kriteria penilaian menggunakan skor 1-4, dimana skor 1 menunjukkan skor terendah dan skor 4 menunjukkan skor tertinggi. Penentuan rentang skala pada kriteria penilaian dapat diperoleh dengan cara rentang skor tertinggi dikurangi skor terendah dibagi dengan skor tertinggi. Berdasarkan penentuan rentang tersebut diperoleh rentang 0,75. Kriteria kelayakan analisis nilai rata-rata yang digunakan disajikan pada Tabel 3.2.

Tabel 3.2 Kriteria Kelayakan Analisis Nilai Rata-rata

Tabel 3.2 Kriteria Kelayakan Analisis Nilai Rata-rata

\begin{tabular}{cl} 
Tabel 3.2 Kriteria Kelayakan Analisis Nilai Rata-rata \\
\hline Rata-rata & \multicolumn{1}{c}{ Kategori Validasi } \\
\hline $3,26-4,00$ & Layak/ valid/ tidak direvisi \\
$2,51-3,25$ & $\begin{array}{l}\text { Cukup layak/ cukup valid/ tidak } \\
\text { direvisi } \\
1,76-2,50\end{array}$ \\
$1,00-1,75$ & $\begin{array}{l}\text { Kurang layak/kurang valid/ } \\
\text { revisi sebagian } \\
\text { Tidak layak/tidak valid/ revisi } \\
\text { total }\end{array}$ \\
\end{tabular}

(Diadaptasi dari Arikunto: 2008)

\footnotetext{
${ }^{6}$ Hobri. MetodologiPenelitianPengembangan.(Jember, : Pena Salsabila, 2010), 35
} 
Pengujian efektivitas modul PAI Pendekatan Sainstifik dilakukan dengan uji-t (independent-sample T-test) untuk melihat adanya perbedaan nilai rata-rata siswa sebelum menggunakan dan setelah menggunakan modul PAI Pendekatan Sainstifik. Sebelum melaksanakan uji-t, terlebih dahulu dilakukan uji prasyarat analisis yang meliputi uji normalitas dan uji homogenitas dengan menggunakan aplikasi IBM SPSS Statistic 21.

Uji normalitas ini bertujuan untuk mengetahui apakah sampel yang diambil berasal dari populasi yang berdistribusi normal atau tidak. Uji normalitas dalam penelitian ini menggunakan tes satu sampel Kolmogorov-Smirnov dalam aplikasi IBM SPSS Statistic 21. Pengujian normalitas data menggunakan uji Kolmogorov-Smirnov dengan hipotesis:

Sampel berasal dari populasi yang berdistribusi

normal

Sampel berasal dari populasi yang berdistribusi tidak normal

Penentuan sampel terdistribusi normal atau tidak berdasarkan ketentuan sebagai berikut.

(1) Nilai Sig. $<0,05$ maka distribusi adalah tidak normal. $\mathrm{H}_{0}$ ditolak.

(2) Nilai Sig. > 0,05 maka distribusi adalah normal. $\mathrm{H}_{0}$ diterima.

\section{Uji Homogenitas}

Uji homogenitas merupakan suatu uji yang dilakukan untuk mengecek apakah kedua sampel yang diperoleh homogen atau tidak (Trihendradi, 2009). Data yang diuji adalah data awal siswa yang merupakan hasil pretes dan juga hasil postes. Uji homogenitas yang digunakan dalam penelitian ini adalah uji Levene dalam aplikasi aplikasi IBM SPSS Statistic 21. Pengujian homogenitas data menggunakan uji Levene dengan hipotesis:

\footnotetext{
0

Kedua kelompok sampel memiliki variansi yang sama

Kedua kelompok sampel memiliki variansi yang tidak sama
}

Penentuan sampel terdistribusi homogen atau tidak berdasarkan ketentuan sebagai berikut.

(1) Nilai Sig. $<0,05$ maka distribusi adalah tidak homogen. $\mathrm{H}_{0}$ ditolak.

(2) Nilai Sig. > 0,05 maka distribusi adalah homogen. $\mathrm{H}_{0}$ diterima. 


\section{Uji-t}

Pembuktian perbedaan pembelajaran menggunakan modul pembelajaran nahwu dengan menggunakan pendekatan sainstifik dengan pembelajaran menggunakan buku teks diuji secara statistik menggunakan uji t (independent-samples $T$ test). Uji t digunakan untuk mengetahui perbedaan dari rerata hasil post-test hasil belajar siswa kelas X SMA yang menggunakan modul pembelajaran nahwu dengan pendekatan sainstifik dengan buku teks. Uji-t dalam penelitian ini menggunakan aplikasi IBM SPSS Statistic 21. Hipotesis statistik penelitian sebagai berikut.

tidak terdapat perbedaan hasil belajar siswa yang menggunakan modul pembelajaran nahwu dengan menggunakan pendekatan sainstifik dengan hasil belajar siswa yang menggunakan buku teks

terdapat perbedaan hasil belajar siswa yang menggunakan modul pembelajaran nahwu dengan menggunakan pendekatan sainstifik dengan hasil belajar siswa yang menggunakan buku teks

Pengambilan keputusan hasil uji t berdasarkan ketentuan sebagai berikut.

(1) Nilai Sig. $<0,05$ maka hasil uji t adalah $\mathrm{H}_{0}$ ditolak.

(2) Nilai Sig. > 0,05 maka hasil uji $\mathrm{t}$ adalah $\mathrm{H}_{0}$ diterima.

Analisis penilaian ahli digunakan untuk mengetahui tingkat kualitas modul yang dilihat dari tiga aspek yakni: 1) aspek bahasa; 2) substansi isi (materi); 3) bentuk penyajian modul yang dikembangkan. Nilai analisis di gali dari lembar evaluasi bahan ajar yang dinilai oleh para ahli. Setiap aspek dinilai dengan rentang nilai 1 sampai dengan 4 berdasarkan skala likert dengan kategori sebagai berikut:

a) Sangat Setuju nilai 4,

b) Setuju nilai 3,

c) Tidak setuju nilai 2 , dan

d) Sangat tidak setuju nilai 1 .

Setelah bahan ajar (modul) dinilai oleh para ahli dan dinyatakan layak untuk digunakan tahapan selanjutnya adalah diujicobakan, penilaian uji coba ini dinilai dari hasil penilaian angket oleh siswa. Penganalisaan angket terlebih dahulu diadakan terhadap setiap peryataan angket. Penetuan krrteria penelitian terhadap modul yang dikembangkan dilakukan berdasarkan kreteria skala likert. ${ }^{7}$ (Sugiono, 2013).

\footnotetext{
${ }^{7}$ Sugiyono, Metode Penelitian \& Pengembangan Research and Development ... , 28
} 
Tahap terakhir adalah menerapkan modul yang telah dikembangkan, kemudian menganalisis hasil implementasinya. Tahap analisis data yang akan dilakukan adalah sebagai berikut: 1) angket yang telah diisi responden diperiksa kelengkapan jawabannya, kemudian disusun sesuai dengan kode jawabanya, 2) mengkuantifikasi jawaban setiap pertanyaan dengan memberikan skor sesuai dengan bobot yang telah ditentukan, 3) membuat tabulasi data, 4) menghitung prosentase dari komponen angket dengan rumus sebagai berikut:

$\mathrm{P}=\frac{\sum X i}{\sum x} \mathrm{x} 100 \%$

Keterangan:

$\mathrm{P}$ : prosentase penilaian,

$\sum x i$ : jumlah jawaban dari subjek, dan

$\sum \mathrm{x}$ : jumlah jawaban tertinggi.

Prosentase yang telah diperoleh kemudian ditransformasikan ke dalam tabel agar pembacaan hasil penelitian menjadi mudah. Penentuan kriteria kualitatif dilakukan dengan cara sebagai berikut:

a) Menetukan presentase skor ideal (skor maksimum) $=100 \%$,

b) Menetukan presentase skor terendah (skor minimum) $=0 \%$,

c) Menetukan range 0 sampai 100,

d) Menentukan interval yang dikehendaki (sangat baik/sesuai, baik, cukup, kurang baik, sangat tidak baik/sesuai), dan

e) Menetukan lebar interval $(100 / 5=20)$.

Range presentase dan kreteria kualitatif dapat ditetapkan berdasarkan langkah (e) di atas, yaitu dapat dilihat pada Tabel 3.2.

Tabel 3.2 Pengambilan Keputusan Revisi Pengembangan

\begin{tabular}{|c|c|c|}
\hline Tingkat Pencapaian & Kualifikasi & Keterangan \\
\hline $81 \%-100 \%$ & Sangat baik & Tidak perlu direvisi \\
$61 \%-80 \%$ & Baik & Tidak perlu direvisi \\
$41 \%-60 \%$ & Cukup & Revisi \\
$21 \%-40 \%$ & Kurang baik & Revisi \\
$0 \%-20 \%$ & Sangat kurang baik & Revisi \\
\hline
\end{tabular}

Subjek Penelitian dan Pengembangan terdiri dari Guru Mapel Nahwu-Shorof kelas X SMA Darul Ulum 3 Peterongan. Pendukung; pakar, dan pemerhati Pendidikan Agama Islam di Pondok Pesantren Darul Ulum Jombang (MPPDU Bidang Pendidikan). Uji terbatas pengembangan modul pembelajaran Nahwu dengan menggunakan pendekatan saintifik dilaksanakan di kelas X IPS 2 (kelas eksperimen) SMA Darul Ulum 3, adapun Uji Luas pengembangan modul pembelajaran Nahwu dengan menggunakan pendekatan saintifik dilaksanakan di kelas X MIPA1dan 2, X IPS1 SMA Darul Ulum 3 Jombang. 


\section{Desain Pengembangan Modul Pembelajaran Nahwu dengan Pendekatan Saintifik}

Desain Pengembangan modul pembelajaran Nahwu dengan menggunakan pendekatan saintifik di SMA Darul Ulum 3 Jombang, peneliti menggunakan model Plomp yang meliputi lima fase, yaitu:

\section{Fase Investigasi Awal (Preliminary Investigation)}

Kegiatan yang dilakukan pada fase ini terfokus pada penghimpunan informasi permasalahan pembelajaran Nahwu terdahulu. Kegiatan pada tahap ini adalah:

Analisis Ujung Depan. Analisis ujung depan ditujukan untuk menentukan masalah dasar yang diperlukan dalam pengembangan bahan pelajaran. Dalam tahap ini dilakukan telaah terhadap kurikulum pondok pesantren Darul Ulum, dan teori-teori pembelajaran yang mendasarinya sehingga diperoleh deskripsi pola pembelajaran yang dianggap ideal.

Kurikulum tingkat satuan pendidikan jenjang pendidikan dasar dan menengah dikembangkan oleh sekolah/Madrasah dan komite sekolah/Madrasah berpedoman pada standar kompetensi lulusan dan standar isi dengan berlandasan kebijakan dari Pimpinan pondok pesantren Darul Ulum dengan menitik beberapa poin. Pertama, berpusat pada potensi, perkembangan, kebutuhan, dan kepentingan peserta didik dan lingkungan. Kurikulum dikembangkan berdasarkan prinsip bahwa peserta didik memiliki posisi sentral untuk mengembangkan kompetensinya agar menjadi manusia yang beriman dan bertakwa kepada Allah SWT, berakhlaq mulia, sehat, berilmu, cakap, kreatif, mandiri dan menjadi warga negara yang demokratis serta bertanggung jawab. Untuk mendukung pencapaian tujuan tersebut pengembangan kompetensi peserta didik disesuaikan dengan potensi, perkembangan, kebutuhan, dan kepentingan peserta didik serta tuntutan lingkungan.

Kedua, Beragam dan terpadu. Kurikulum dikembangkan dengan memperhatikan keragaman karakteristik peserta didik, kondisi asal santri, dan jenjang serta jenis pendidikan, tanpa membedakan adat istiadat, serta status sosial ekonomi dan gender. Kurikulum meliputi substansi komponen muatan wajib kurikulum, muatan lokal, dan pengembangan diri secara terpadu, serta disusun dalam keterkaitan dan kesinambungan yang bermakna dan tepat antar substansi. Ketiga, tanggap terhadap perkembangan ilmu pengetahuan, teknologi dan perubahan Budaya. Kurikulum dikembangkan atas dasar kesadaran bahwa ilmu pengetahuan, teknologi dan perkembangan budaya berkembang secara dinamis, dan oleh karena itu semangat dan isi kurikulum mendorong peserta didik untuk mengikuti dan memanfaatkan secara tepat perkembangan ilmu pengetahuan, teknologi, dan perkembangan budaya pada saat itu. Keempat, 
relevan dengan kebutuhan kehidupan. Pengembangan kurikulum dilakukan dengan melibatkan pemangku kepentingan (stakeholders) untuk menjamin relevansi pendidikan dengan kebutuhan kehidupan, termasuk di dalamnya kehidupan kemasyarakatan, dunia usaha dan dunia kerja. Oleh karena itu pengembangan keterampilan pribadi meliputi : keterampilan berpikir, keterampilan sosial, keterampilan akademik, dan keterampilan vokasional merupakan keniscayaan.

Kelima, menyeluruh dan berkesinambungan Substansi kurikulum mencakup keseluruhan dimensi kompetensi, bidang kajian keilmuan dan mata pelajaran yang direncanakan dan disajikan secara berkesinambungan antar semua jenjang pendidikan. Keenam, belajar sepanjang hayat ( Minal Mahdi Ilal Lahdi ). Kurikulum diarahkan kepada proses pengembangan, pembudayaan dan pemberdayaan peserta didik yang berlangsung sepanjang hayat. Kurikulum mencerminkan keterkaitan antara unsur-unsur pendidikan formal, nonformal dan informal, dengan memperhatikan kondisi dan tuntutan lingkungan yang selalu berkembang serta arah pengembangan manusia seutuhnya.

Kurikulum Pendidikan Agama Islam (PAI) Kepesantrenan adalah kurikulum khas Pondok Pesantren Darul Ulum dan wajib dilaksanakan pada semua jenjang pendidikan formal unit pendidikan di lingkungan Pondok Pesantren Darul Ulum. Jumlah beban belajar adalah 12 jam pelajaran untuk tiap-tiap tingkatan (kelas) dengan durasi tatap muka per jam sama dengan standar kurikulum kemendikbud/kemenag.

Hasil pengamatan lingkungan belajar di SMA Darul Ulum 3 Jombang memiliki lingkungan belajar yang cukup kondusif karena tempat belajar jauh dari lokasi yang bising, sarana prasarana perlengkapan sekolah juga sangat mendukung untuk terciptanya proses belajar mengajar yang baik. Selain sarana prasarana belajar yang mendukung pembelajaran . di SMA Darul Ulum 3 Jombang juga memiliki taman dan pepohonan yang rindang sehingga memberikan nuasa sejuk dalam lingkungan sekolah. Lingkungan belajar di SMA Darul Ulum 3 Jombang juga ditunjang lingkungan keakraban dan kerjasama guru karyawan yang baik dan harmonis dalam proses pendampingan terhadap peserta didik.

Input Peserta didik di SMA Darul Ulum 3 Jombang mayoritas lulusan dari jenjang SLTP negeri/swasta dengan perbandingan 75\% lulusan SMP negeri/swasta dan $25 \%$ lulusan dari Madrasah Tsanawiyah negeri/swasta. Mayoritas siswa tinggal di asrama atau pesantren, sehingga peserta didik di SMA Darul Ulum 3 Jombang tidak terdapat banyak perbedaan sikap peserta didik yang mencolok. 
Hasil observasi kegiatan proses belajar mengajar mata pelajaran Nahwu Shorof pada siswa kelas XI di SMA Darul Ulum 3 Jombang didapatkan gambaran bahwa masih banyak peserta didik yang cendrung pasif dalam proses pembelajaran, dan dari hasil wawancara dengan siswa, siswa merasakan materi pelajaran Nahwu Shorof lebih sulit dipahami. Dalam pembelajaran Nahwu Shorof banyak materi menghafal yang rumit, siswa juga merasakan bahwa buku teks pelajaran susah untuk dipahami. Selain buku teks susah untuk dipahami maksudnya, metode dan penyampaian pembelajaran oleh guru dirasa siswa kurang variatif serta kurang memberikan keleluasaan dan bimbingan kepada siswa untuk mencoba dan mepraktekan penerapan Nahwu Shorof dalam memahami teks-teks berbahasa Arab. Berdasarkan analisis kebutuhan di Bab III dan studi hasil pendahuluan maka dipandang perlu suatu pembaharuan dalam proses pembelajaran ekonomi sub bab akuntasni yaitu diperlukannya modul pembelajaranyang menerapkan langkah-langkah dalam pendekatan saintifik yang dapat mengoptimalkan kemampuan siswa meningkatkan kemampuan aplikatif pembelajaran Nahwu Shorofdengan cara mengembangkan modul pembelajaran Nahwu Shorof dengan menggunakan pendekatan saintifik.

Guru mata pelajaran Nahwu Shorof di SMA Darul Ulum 3 Jombang berjumlah 3 orang, dengan kualifikasi S1 Pendidikan Bahasa Arab (PBA). tiga tenaga pengajar tesebut setiap minggunya mengajar mata pelajaranNahwu Shorof sejumlah 20 jam pelajaran dengan penghitungan mengajar kelas X sejumlah 8 jam pelajaran, mengajar kelas XI 6 jam pelajaran dan mengajar kelas XII 16 jam pelajaran. Segi keprofesionalan guru untuk guru mata pelajaran Nahwu Shorof kedua guru Nahwu Shorof di SMA Darul Ulum 3 Jombang sudah masuk kategori guru profesioanl karena telah mendapatkan sertifikat pendidik melalui jalur PLPG pada tahun 2009. Hasil observasi pada proses pembelajaran di dalam kelas guru Nahwu Shorof khususnya pada saat mengajarkan materi Nahwu masih menitikberatkan pada penggunaan buku paket yang diteritkan oleh percetakan, sehingga guru belum mengoptimalkan diri untuk menyusun modul atau bahan ajar yang sudah disesuaikan dengan model pembelajaran yang dipilih. Hasil wawancara dengan guru Nahwu Shorof, pada saat proses pembelajaran Nahwu Shorof guru masih sering menggunakan model pembelajaran yang kurang melibatkan siswa dalam proses pembelajaran. Guru mata pelajaran Nahwu Shorof di SMA Darul Ulum 3 Jombang dari hasil wawancara juga mengakui bahwasanya peserta didiknya mempunyai kemampuan yang lebih rendah pada saat mengerjakan soal atau membaca kitab kuning karena menurut pengaplikasian materi Nahwu Shorof masih terfokus pada teoritis sehingga siswa 
kurang terbiasa mengaplikasikannya dalam membaca kitab kuning serta kemandirian siswa dalam mengerjakan soal-soal latihan Nahwu Shorof masih sangat kurang.

Analisis materi ditujukan untuk memilih dan menetapkan, merinci dan menyusun secara sistematis materi ajar yang relevan untuk diajarkan berdasarkan analisis ujung depan. Dalam penelitian ini, penulis mengadopsi materi Nahwu dari kitab Imrithi dan Jurumiyah dan juga mengadopsi dari kitab pasal-pasal dalam kitabFatkhul Qorib yang meliputi kitabut taharah dan kitabus shalat dalam implementasi pengembangan contoh-contoh susunan kalimat yang berhubungan dengan materi pembelajaran Nahwu.

Kegiatan yang dilakukan pada fase Desain (Design) adalah mendesain (merancang) modul pembelajaran Nahwu dengan menggunakan pendekatan saintifik melalui beberapa tahapan. Pertama, memilih format modul pembelajaran Nahwu. Kedua, menyusun modul pembelajaran Nahwu disesuaikan dengan petunjuk teknis penyusunan modul. Ketiga, mengaplikasikan model pembelajaran dalam pendekatan saintifik yang meliputi mind mapping, inquiry,problem posing, dan practice and drill dalam menyusun modul pembelajaran Nahwu.

Fase Realisasi/Konstruksi (Realization/Construction) menghasilkan produk pengembangan berdasarkan desain yang telah dirancang. Produknya adalah bahan ajar yang berupa modul pembelajaran Nahwu dengan menggunakan pendekatan saintifik dengan mengaplikasikan model pembelajaran mind mapping, inquiry.

Pada Fase Tes, Evaluasi, dan Revisi (Test, Evaluation,and Revision) dilakukan 2 kegiatan utama. Pertama, Kegiatan Validasi. Kegiatan ini dilakukan pada waktu memvalidasi modul pembelajaran Nahwu. Kegiatan ini berisi penilaian Modul oleh Ahli Materi dan Penilaian Modul oleh Praktisi. Penilaian ahli materi ini dilakukan oleh Dosen ahli materi Nahwu Shorof dengan kualifikasi doktor bidang pendidikan Bahasa Arab, hal yang dinilai dalam modul ini adalah aspek bahasa, aspek kelayakan isi, dan aspek kelayakan penyajian. Hasil penilaian ahli materi dapat dilihat di Tabel 4.1 di bawah ini:

Tabel 4.1 Hasil Penilaian Ahli Materi

\begin{tabular}{|c|c|c|}
\hline INDIKATOR PENILAIAN & BUTIR PENILAIAN & SKOR \\
\hline \multicolumn{2}{|l|}{ Aspek Penilaian Bahasa } & \\
\hline a. Lugas & $\begin{array}{ll}\text { 1. } & \text { Ketepatan struktur kalimat } \\
\text { 2. } & \text { Keefektifan kalimat } \\
\text { 3. } & \text { Kebakuan istilah }\end{array}$ & $\begin{array}{l}4 \\
4 \\
4\end{array}$ \\
\hline b. Komunikatif & $\begin{array}{l}\text { 1. Keterbacaan pesan } \\
\text { 2. Ketepatan penggunaan kaidah bahasa }\end{array}$ & $\begin{array}{l}4 \\
4\end{array}$ \\
\hline c. Dialogis dan Interaktif & $\begin{array}{l}\text { 1. Kemampuan memotivasi pesan atau informasi } \\
\text { 2. Kemampuan mendorong berpikir kritis }\end{array}$ & $\begin{array}{l}4 \\
3\end{array}$ \\
\hline
\end{tabular}




\begin{tabular}{|c|c|c|c|}
\hline $\begin{array}{ll}\text { d. } & \text { Kesesuain dengan } \\
\text { tingkat perkembangan } \\
\text { peserta didik }\end{array}$ & \multicolumn{2}{|c|}{$\begin{array}{l}\text { 1. Kesesuaian perkembangan intelektual peserta didik. } \\
\text { 2. Kesesuaian perkembangan emosional peserta didik. }\end{array}$} & $\begin{array}{l}3 \\
4\end{array}$ \\
\hline $\begin{array}{ll}\text { e. } & \text { Keruntutan dan } \\
& \text { Keterpaduan alur piker }\end{array}$ & & $\begin{array}{l}\text { Setentuan dan keterpaduan antar kegiatan belajar } \\
\text { Keruntutan dan keterpaduan antar kegiatan belajar }\end{array}$ & $\begin{array}{l}3 \\
3\end{array}$ \\
\hline $\begin{array}{l}\text { f. Penggunaan istilah dan } \\
\text { simbol }\end{array}$ & & $\begin{array}{l}\text { Konsistensi penggunaan istilah } \\
\text { Konsistensi penggunaan simbol }\end{array}$ & $\begin{array}{l}4 \\
4\end{array}$ \\
\hline \multicolumn{4}{|l|}{ Aspek Kelayakan Isi } \\
\hline \multicolumn{2}{|c|}{$\begin{array}{l}\text { Kesesuaian materi dengan KI } \\
\text { dan KD }\end{array}$} & $\begin{array}{ll}\text { 1. } & \text { Kelengkapan materi } \\
\text { 2. } & \text { Keluasan materi } \\
\text { 3. } & \text { Kedalaman materi }\end{array}$ & $\begin{array}{l}3 \\
4 \\
3\end{array}$ \\
\hline \multicolumn{2}{|l|}{ b. Keakuratan materi } & $\begin{array}{l}\text { 1. Keakuratan konsep dan definisi } \\
\text { 2. Keakuratan prinsip } \\
\text { 3. Keakuratan fakta dan data } \\
\text { 4. Keakuratan contoh } \\
\text { 5. Keakuratan soal } \\
\text { 6. Keakuratan gambar, diagram, symbol dan } \\
\text { ilustrasi. } \\
\text { 7. Keakuratan acuan pustaka }\end{array}$ & $\begin{array}{l}3 \\
3 \\
3 \\
2 \\
3 \\
4 \\
3\end{array}$ \\
\hline \multicolumn{2}{|l|}{ c. Pendukung materi pelajaran } & $\begin{array}{ll}\text { 1. } & \text { Penalaran } \\
\text { 2. } & \text { Keterkaitan } \\
\text { 3. } & \text { Komunikasi } \\
\text { 4. } & \text { Penerapan } \\
\text { 5. } & \text { Kemenarikan materi } \\
\text { 6. } & \text { Mendorong untuk mencari informasi lebih } \\
& \text { jauh }\end{array}$ & $\begin{array}{l}4 \\
4 \\
3 \\
4 \\
4 \\
4\end{array}$ \\
\hline \multicolumn{4}{|l|}{ Aspek Kelayakan Penyajian } \\
\hline a. Teknik penyajian & & $\begin{array}{l}\text { 1. Konsistensi sistematika sajian dalam kegiatan } \\
\text { belajar. } \\
\text { 2. Keruntutan penyajian. }\end{array}$ & $\begin{array}{l}3 \\
4\end{array}$ \\
\hline b. Pendukung penyajian & & $\begin{array}{l}\text { 1. Pembangkit motivasi belajar pada awal KD. } \\
\text { 2. Contoh-contoh soal dalam setiap kegiatan } \\
\text { belajar. } \\
\text { 3. Soal latihan pada setiap akhir kegiatan } \\
\text { belajar. } \\
\text { 4. Kunci jawaban soal latihan } \\
\text { 5. Umpan balik soal latihan. } \\
\text { 6. Pengantar. } \\
\text { 7. Daftar pustaka } \\
\text { 8. Rangkuman }\end{array}$ & $\begin{array}{l}3 \\
2 \\
3 \\
3 \\
2 \\
2 \\
3 \\
2\end{array}$ \\
\hline c. Penyajian Pembelajaran & & 1. Keterlibatan peserta didik. & 3 \\
\hline d. Kelengkapan Penyajian & & $\begin{array}{l}\text { 1. } \text { Bagian pendahuluan. } \\
\text { 2. } \text { Bagian isi. } \\
\text { 3. } \text { Bagian penutup. }\end{array}$ & $\begin{array}{l}3 \\
4 \\
3\end{array}$ \\
\hline
\end{tabular}




\begin{tabular}{|lc|}
\hline Skor Total & 142 \\
\hline Prosentase Pencapaian & $82,5 \%$ \\
\hline
\end{tabular}

Dari besaran angka yang didapat 82,5\% diatas > dari skor tingkat pencapian $60 \%$ sehingga dapat disimpulkan bahwa modul pembelajaran Nahwu layak untuk diggunakan. Penilaian Modul oleh Praktisi dilakukan oleh guru Nahwu Shorof yang mengajar di kelas X dengan kualifikasi minimal S1 pendidikan bahasa Arab atau S1 sastra Arab, hal yang dinilai dalam modul ini adalah aspek penilaian bahasa, aspek kelayakan isi dan aspek kelayakan penyajian. Hasil penilaian oleh praktisi dapat dilihat di Tabel 4.2 di bawah ini:

Tabel 4.2 Hasil Penilaian Praktisi

\begin{tabular}{|c|c|c|}
\hline INDIKATOR PENILAIAN & BUTIR PENILAIAN & SKOR \\
\hline \multicolumn{3}{|l|}{ Aspek Penilaian Bahasa } \\
\hline a. Lugas & $\begin{array}{ll}\text { 1. } & \text { Ketepatan struktur kalimat } \\
\text { 2. } & \text { Keefektifan kalimat } \\
\text { 3. } & \text { Kebakuan istilah }\end{array}$ & $\begin{array}{l}4 \\
4 \\
4\end{array}$ \\
\hline b. Komunikatif & $\begin{array}{l}\text { 1. Keterbacaan pesan } \\
\text { 2. Ketepatan penggunaan kaidah bahasa }\end{array}$ & $\begin{array}{l}4 \\
4\end{array}$ \\
\hline c. Dialogis dan Interaktif & $\begin{array}{l}\text { 1. Kemampuan memotivasi pesan atau informasi } \\
\text { 2. Kemampuan mendorong berpikir kritis }\end{array}$ & $\begin{array}{l}4 \\
4\end{array}$ \\
\hline $\begin{array}{l}\text { d. Kesesuain dengan tingkat } \\
\text { perkembangan peserta didik }\end{array}$ & $\begin{array}{l}\text { 1. Kesesuaian perkembangan intelektual peserta didik. } \\
\text { 2. Kesesuaian perkembangan emosional peserta didik. }\end{array}$ & $\begin{array}{l}3 \\
3\end{array}$ \\
\hline $\begin{array}{ll}\text { e. } & \text { Keruntutan dan } \\
& \text { Keterpaduan alur piker }\end{array}$ & $\begin{array}{l}\text { 1. Ketentuan dan keterpaduan antar kegiatan belajar } \\
\text { 2. Keruntutan dan keterpaduan antar kegiatan belajar }\end{array}$ & $\begin{array}{l}3 \\
3\end{array}$ \\
\hline $\begin{array}{l}\text { f. Penggunaan istilah dan } \\
\text { simbol }\end{array}$ & $\begin{array}{l}\text { 1. Konsistensi penggunaan istilah } \\
\text { 2. Konsistensi penggunaan simbol }\end{array}$ & $\begin{array}{l}4 \\
4\end{array}$ \\
\hline \multicolumn{3}{|l|}{ Aspek Kelayakan Isi } \\
\hline $\begin{array}{ll}\text { d. } & \text { Kesesuaian materi dengan } \\
\text { KI dan KD }\end{array}$ & $\begin{array}{ll}\text { 1. } & \text { Kelengkapan materi } \\
\text { 2. } & \text { Keluasan materi } \\
\text { 3. } & \text { Kedalaman materi }\end{array}$ & $\begin{array}{l}3 \\
3 \\
3\end{array}$ \\
\hline e. Keakuratan materi & $\begin{array}{l}\text { 1. Keakuratan konsep dan definisi } \\
\text { 2. Keakuratan prinsip } \\
\text { 3. Keakuratan fakta dan data } \\
\text { 4. Keakuratan contoh } \\
\text { 5. Keakuratan soal } \\
\text { 6. Keakuratan gambar, diagram, symbol dan ilustrasi. } \\
\text { 7. Keakuratan acuan pustaka }\end{array}$ & $\begin{array}{l}3 \\
3 \\
3 \\
3 \\
3 \\
3 \\
3\end{array}$ \\
\hline f. $\quad$ Pendukung materi pelajaran & $\begin{array}{ll}\text { 1. } & \text { Penalaran } \\
\text { 2. } & \text { Keterkaitan } \\
\text { 3. } & \text { Komunikasi } \\
\text { 4. } & \text { Penerapan }\end{array}$ & $\begin{array}{l}4 \\
4 \\
4 \\
4\end{array}$ \\
\hline
\end{tabular}




\begin{tabular}{|c|c|c|}
\hline & $\begin{array}{ll}\text { 5. } & \text { Kemenarikan materi } \\
\text { 6. } & \text { Mendorong untuk mencari informasi lebih jauh }\end{array}$ & $\begin{array}{l}4 \\
4\end{array}$ \\
\hline \multicolumn{3}{|l|}{ Aspek Kelayakan Penyajian } \\
\hline a. Teknik penyajian & $\begin{array}{l}\text { 1. Konsistensi sistematika sajian dalam kegiatan belajar. } \\
\text { 2. Keruntutan penyajian. }\end{array}$ & 4 \\
\hline b. Pendukung penyajian & $\begin{array}{l}\text { 1. Pembangkit motivasi belajar pada awal KD. } \\
\text { 2. } \text { Contoh-contoh soal dalam setiap kegiatan belajar. } \\
\text { 3. Soal latihan pada setiap akhir kegiatan belajar. } \\
\text { 4. Kunci jawaban soal latihan } \\
\text { 5. Umpan balik soal latihan. } \\
\text { 6. Pengantar. } \\
\text { 7. Daftar pustaka } \\
\text { 8. Rangkuman }\end{array}$ & $\begin{array}{l}3 \\
3 \\
3 \\
3 \\
2 \\
3 \\
3 \\
2\end{array}$ \\
\hline c. Penyajian Pembelajarn & 1. Keterlibatan peserta didik. & 3 \\
\hline $\begin{array}{ll}\text { d. } & \text { Kelengkapan Penyajian }\end{array}$ & $\begin{array}{ll}\text { 1. } & \text { Bagian pendahuluan. } \\
\text { 2. } & \text { Bagian isi. } \\
\text { 3. } & \text { Bagian penutup. }\end{array}$ & $\begin{array}{l}3 \\
3 \\
3\end{array}$ \\
\hline \multicolumn{3}{|c|}{$\begin{array}{ll}\text { Skor Total } & 144\end{array}$} \\
\hline Prosentase Pencapaian & $83,7 \%$ & \\
\hline
\end{tabular}

Dari besaran angka yang didapat $83,7 \%$ diatas > dari skor tingkat pencapian $60 \%$ sehingga dapat disimpulkan bahwa modul pembelajaran Nahwu layak untuk digunakan.

Tahap revisi desain ini setelah dilakukan validasi RPP dan modul oleh para ahli, maka saran-saran perbaikan yang diberikan oleh para ahli harus diimplementasikan dalam modul karena hasil validasi dan saran pemberian saran oleh para ahli akan dapat mengetahui kelemahan modul. Berdasarkan komentar, saran, kritik, dan hasil penilaian angket dari validator menunjukkan bahwa terdapat beberapa bagian dari modul pembelajaran yang memerlukan perbaikan. Perbaikan-perbaikan bahan ajar berdasarkan komentar, saran, kritik, dan hasil penilaian angket ditunjukkan dalam Tabel 4.4 .

Tabel 4.4 Revisi Berdasarkan Komentar dan Saran dari Validator

\begin{tabular}{lll}
\hline Aspek & Komentar dan Saran & Hasil Revisi \\
\hline Kelayakan isi & $\begin{array}{l}\text { Penyajian contoh sebaiknya } \\
\text { kontekstual }\end{array}$ & $\begin{array}{l}\text { Penyajian contoh diganti dengan } \\
\text { contoh-contoh kalimah yang } \\
\text { kontekstual }\end{array}$ \\
\hline & $\begin{array}{l}\text { Kata kalimat isim diganti } \\
\text { dengan kata kalimah isim } \\
\text { untuk membedakan kalimat } \\
\text { dalam bahasa Indonesia. }\end{array}$ & $\begin{array}{l}\text { Kata katimat isim diganti dengan } \\
\text { katimah isim }\end{array}$ \\
\hline
\end{tabular}


Kelayakan penyajian
Sebaiknya Teks dipilih berdasarkan kebutuhan siswa akan mufrodat.
Teks diganti berdasarkan kebutuhan siswa akan mufrodat.

\section{Kegiatan Ujicoba Lapangan}

Tahap pengujian efektivitas modul pembelajaran Nahwu dengan menggunakan pendekatan Sainstifik dilakukan setelah uji coba lapangan pada kelas eksperimen. Desain penelitian menggunakan desain pretest-posttest control group design dengan menggunakan uji normalitas, uji homogenitas dan uji-t. Pada fase ini solusi yang dihasilkan didasarkan pada hasil evaluasi ujicoba penggunakan modul pembelajaran Nahwu dalam kegiatan pembelajaran di kelas X MIPA dan X IPS di SMA Darul Ulum 3 Jombang. Solusi ini diharapkan bisa lebih menyempurnakan penyusunan modul pembelajaran Nahwu pada tahun ajaran selanjutnya. Berdasarkan komentar, saran, kritik, dan hasil penilaian angket dari validator dan siswa menunjukkan bahwa terdapat beberapa bagian dari bahan ajar yang memerlukan perbaikan. Perbaikan-perbaikan bahan ajar berdasarkan komentar, saran, kritik, dan hasil penilaian angket.

\section{Pelaksanaan Pembelajaran}

Modul pembelajaran Nahwu dengan menggunakan pendekatan saintifik dilaksanakan dalam pembelajaran Nahwu Shorof kelas di kelas X MIPA1dan 2, X IPS1 SMA Darul Ulum 3 Jombang. Hasil pengolahan instrumen penilaian perangkat pembelajaran (RPP) oleh ahli materi dan praktisi bedasarkan Tabel 4.3 didapatkan skor tingkat pencapaian sebesar 85,7\%.

Tabel 4.3 Hasil Penilian Perangkat Pembelajaran (RPP) oleh Ahli Praktisi.

\begin{tabular}{|c|l|c|}
\hline No. & \multicolumn{1}{|c|}{ Aspek yang dinilai } & Total Skor \\
\hline 1 & Kesesuaian antar kompetensi dasar dari KI1, KI2, KI3, dan KI4 & 3 \\
\hline 2 & $\begin{array}{l}\text { Kesesuaian rumusan indikator pencapaiandengan kompetensi dasar (dari KI1, KI2, } \\
\text { KI3, dan KI4) yang akan dicapai. }\end{array}$ & 4 \\
\hline 3 & Kesesuaian perumusan tujuan pembelajaran dengan indikator pencapaian kompetensi & 3 \\
\hline 4 & $\begin{array}{l}\text { Kesesuaian materi pembelajaran dengan indikator dan kompetensi dasar yang akan } \\
\text { dicapai }\end{array}$ & 3 \\
\hline 5 & $\begin{array}{l}\text { Kejelasan dan urutan materi ajar. } \\
\text { Kesesuaian strategi pembelajaran (metode dan pendekatan) dengan tujuan } \\
\text { pembelajaran dan materi ajar }\end{array}$ & 3 \\
\hline 7 & \begin{tabular}{l} 
Kesesuaian strategi pembelajaran dengan karakteristik peserta didik \\
Kejelasan skenario pembelajaran (langkah-langkah kegiatan pembelajaran) dengan \\
\hline 8
\end{tabular} & $\begin{array}{l}\text { Skenario pembelajaran (langkah-langkah kegiatan pembelajaran) menggambarkan } \\
4\end{array}$ \\
\hline
\end{tabular}




\begin{tabular}{|c|l|c|}
\hline & active learning dan mencerminkan scientific learning & \\
\hline 10 & Ketepatan kegiatan penutup dalam pembelajaran & 2 \\
\hline 11 & $\begin{array}{l}\text { Penilaian mencakup aspek-aspek kompetensi dasar dari KI1, KI2, KI3, dan KI4 yang } \\
\text { harus dicapai }\end{array}$ & 3 \\
\hline 12 & Kesesuaian teknik penilaian dengan indikator/kompetensi yang akan dicapai & 4 \\
\hline 13 & Kelengkapan perangkat penilaian (soal, kunci, rubrik penilaian) & 3 \\
\hline 14 & Keterpaduan dan kesinkronan antar komponen dalam RPP & 48 \\
\hline
\end{tabular}

Dari besaran angka yang didapat $85,7 \%$ diatas > dari skor tingkat pencapian $60 \%$ sehingga dapat disimpulkan bahwa perangkat pembelajaran (RPP) layak untuk diggunakan.

\section{Efektivitas Penggunaan Modul Pembelajaran Nahwu Berbasis Pendekatan Saintifik}

Tingkat efektifitas modul pembelajaran nahwu dengan menggunakan pendekatan saintifik di SMA Darul Ulum 3 Jombang diukur melalui uji normalitas, uji homogenitas, dan uji-t pada kelas kontrol dan kelas eksperimen. Tahap pengujian efektivitas modul pembelajaran Nahwu dengan menggunakan pendekatan Sainstifik dilakukan setelah uji coba lapangan pada kelas eksperimen. Desain penelitian menggunakan desain pretest-posttest control group design.

\section{Uji Normalitas}

Pengambilan data dilakukan di awal pembelajaran dan di akhir pembelajaran materi nahwu (kalimah isim, tanda dan pembagiannya). Awal kegiatan pembelajaran dilakukan prates dan di akhir pembelajaran dilakukan pascates di kelas kontrol dan eksperimen. Data hasil prates dan pascates pada kelas kontrol dan kelas eksperimen diuji normalitasnya menggunakan uji Kolmogorov-Smirnov dalam aplikasi IBM SPSS Statistic 21.

Tabel 4.5 Statistik Deskriptif Hasil Prates Kelas Kontrol dan Kelas Eksperimen

\begin{tabular}{lccccc}
\hline & $\mathrm{N}$ & Mean & Std. Deviation & Minimum & Maximum \\
\hline Prates kelas control & 34 & 57,66 & 13,331 & 34 & 90 \\
\hline Prates kelas eksperimen & 32 & 52,25 & 12,718 & 30 & 88 \\
\hline
\end{tabular}




\begin{tabular}{lcllll}
\hline & \multirow{2}{*}{} & \multicolumn{2}{c}{ Kolmogorov-Smirnov } & Deskripsi \\
\cline { 3 - 5 } & & Statistic & df & Sig. & Data terdistribusi \\
& 34 & 0,079 & 32 & 0,200 & normal \\
\hline Prates kelas control & 32 & 0,133 & 32 & 0,163 \\
\hline Prates kelas eksperimen & & & & \\
\hline
\end{tabular}

Jika nilai Sig. sampel $>5 \%$ maka data tersebut terdistribusi secara normal dan sebaliknya jika nilai Sig. sampel $<5 \%$ maka data tersebut tidak terdistribusi secara normal. Berdasarkan Tabel 4.6 didapatkan data prates nilai Sig. sampel untuk kelas kontrol sebesar 0,200 dan eksperimen sebesar 0,163 sehingga data kedua kelas sampel terdistribusi normal. Saat pembelajaran materi pokok nahwu (kalimah isim, tanda dan pembagiannya) kedua kelas diberikan perlakuan yang berbeda. Kelas kontrol menggunakan buku teks dan kelas eksperimen menggunakan modul nahwu dengan menggunakan pendekatan Sainstifik. Setelah akhir pembelajaran materi nahwu (kalimah isim, tanda dan pembagiannya), kedua kelas dilakukan pascates. Data hasil pascates diuji normalitas datanya menggunakan uji Kolmogorov-Smirnov dalam aplikasi IBM SPSS Statistic 21.

Tabel 4.7 Statistik Deskriptif Hasil Pascates Kelas Kontrol dan Kelas Eksperimen

\begin{tabular}{lccccc}
\hline & N & Mean & Std. Deviation & Minimum & Maximum \\
\hline Prates kelas control & 34 & 71,88 & 9,517 & 50 & 92 \\
\hline Prates kelas eksperimen & 32 & 77,31 & 8,837 & 58 & 96 \\
\hline
\end{tabular}

Tabel 4.8 Normalitas Pascates Kelas Kontrol dan Kelas Eksperimen

\begin{tabular}{|c|c|c|c|c|c|}
\hline & \multirow[b]{2}{*}{$\mathrm{N}$} & \multicolumn{3}{|c|}{$\begin{array}{l}\text { Kolmogorov- } \\
\text { Smirnov }\end{array}$} & Deskripsi \\
\hline & & $\begin{array}{l}\text { Statis } \\
\text { tic }\end{array}$ & $\begin{array}{l}\mathrm{D} \\
\mathrm{f}\end{array}$ & Sig. & $\begin{array}{l}\text { Data } \\
\text { terdistribusi } \\
\text { normal }\end{array}$ \\
\hline Prates kelas kontrol & 34 & 0,114 & 32 & 0,200 & \\
\hline Prates kelas eksperimen & 32 & 0,151 & 32 & 0,062 & \\
\hline
\end{tabular}

Berdasarkan Tabel 4.8 didapatkan data pascates nilai Sig. sampel untuk kelas kontrol sebesar 0,200 dan eksperimen sebesar 0,062. Nilai Sig. sampel > 5\% maka data kedua kelas sampel terdistribusi normal. 


\section{Uji Homogenitas}

Data hasil Prates dan pascates diuji homogenitas datanya menggunakan uji Levene dalam aplikasi IBM SPSS Statistic 21. Hasil perhitungan nilai prates dan pascates untuk uji Levene ditunjukkan Tabel 4.9.

Tabel 4.9 Hasil Uji Homogenitas Menggunakan Uji Levene pada Kelas Kontrol dan Kelas Eksperimen

\begin{tabular}{lccc}
\hline & \multicolumn{2}{c}{$\begin{array}{c}\text { Levene Test Equality of } \\
\text { Variances }\end{array}$} & Deskripsi \\
& F & Sig. & $\begin{array}{c}\text { Data } \\
\text { homogeny }\end{array}$ \\
\cline { 1 - 2 } Prates kelas control & 0,101 & 0,752 & \\
\cline { 1 - 2 } Prates kelas eksperimen & 0,329 & 0,569 & \\
\hline
\end{tabular}

Berdasarkan Tabel 4.9 didapatkan nilai Sig. sampel prates dan pascates sebesar 0,752 dan 0,569. Sig. prates sebesar 0,752 > 5\% maka data prates adalah homogen. Sig. pascates sebesar 0,569 > 5\% maka data pascates adalah homogen. Jadi kedua data prates dan pascates merupakan data yang homogen.

\section{Uji-t}

Jumlah sampel yang digunakan dalam penelitian sebanyak 66 siswa yang terdiri atas kelas kontrol sebanyak 34 siswa dan kelas eksperimen sebesar 32 siswa. Berdasarkan Tabel 4.9 hasil uji t didapatkan bahwa nilai Sig. (2-tailed) untuk pascates sebesar 0,030. Sig. (2-tailed) $0,030<5 \%$ maka hasil uji $\mathrm{t}$ adalah $\mathrm{H}_{0}$ ditolak. Jadi, terdapat perbedaan hasil belajar siswa yang menggunakan modul pembelajaran nahwu dengan menggunakan Pendekatan sainstifik dengan hasil belajar siswa yang menggunakan buku teks.

Tabel 4.10 Hasil Uji-T

\begin{tabular}{llllll}
\hline & $\mathrm{t}$ & Df & $\begin{array}{l}\text { Sig. } \\
\text { tailed })\end{array}$ & $\begin{array}{l}\text { Mean } \\
\text { Difference }\end{array}$ & $\begin{array}{l}\text { Std. Error } \\
\text { Difference }\end{array}$ \\
\hline Prates & 1,957 & 64 & 0,055 & $-6,309$ & 3,224 \\
\hline Pascates & - & 64 & 0,030 & 5,195 & 2,339 \\
& 2,221 & & & & \\
\hline
\end{tabular}

\section{Kelebihan dan Kekurangan}

Berdasarkan saran dan komentar pakar ahli materi dan praktisi (validator) dapat ditemukan beberapa kelebihan dan kekurangan dari modul pembelajaran Nahwu dengan menggunakan pendekatan saintifik. Kelebihan modul Pembelajaran Nahwu dengan 
menggunakan pendekatan saintifik: a) Secara umum modul pembelajaran nahwu ini bagus dan mempermudah siswa; b) Pembelajaran siswa lebih efektif, dari teori langsung bisa aplikasi ke latihan soal; c) Meningkatkan motivasi siswa untuk belajar secara mandiri; d) Pembelajaran lebih menarik karena bersifat aplikatif ke dalam pembelajaran baca kitab kuning; e) Ilustrasi yang disajikan dalam modul bisa mengubah image bahwa pelajaran Nahwu yang sulit berubah menjadi mudah.

Kekurangan Modul Pembelajaran Nahwu dengan menggunakan pendekatan saintifik adalah: a) Membutuhkan biaya yang lebih dalam pengadaan dan penggadaan modul pembelajaran; b) Penyajian contoh-contoh dalam materi kurang kontekstual; c) Pemilihan teks kurang disesuaikan dengan kebutuhan siswa akan mufrodat; d) Akumulasi nilai dari masingmasing indikator pencapaian kompetensi kurang terdeteksi.

Berdasarkan kuesioner yang telah diisi oleh responden, dalam hal ini adalah siswa kelas X IPS 2 (kelas eksperimen) SMA Darul Ulum 3 Jombang sejumlah 34 siswa, kelebihan dan kekurangan modul pembelajaran nahwu dengan menggunakan pendekatan saintifik tercantum dalam tabel 4.11 berikut ini.

Tabel 4.11 Instrumen penelitian kelebihan dan kekurangan modul pembelajaran nahwu.

\begin{tabular}{|c|c|c|}
\hline No. & Pernyataan & Skor \\
\hline 1 & $\begin{array}{l}\text { Pembelajaran Nahwu menggunakan modul berbasis saintifik dapat memudahkan siswa } \\
\text { dalam belajar. }\end{array}$ & $83 \%$ \\
\hline 2 & $\begin{array}{l}\text { Pembelajaran Nahwu dengan menggunakan modul berbasis saintifik dapat } \\
\text { meningkatkan motivasi siswa dalam mempelajari ilmu Nahwu. }\end{array}$ & $66 \%$ \\
\hline 3 & $\begin{array}{l}\text { Pembelajaran Nahwu dengan menggunakan modul berbasis saintifik dapat } \\
\text { meningkatkan kemandirian siswa dalam mempelajari ilmu Nahwu. }\end{array}$ & $83 \%$ \\
\hline 4 & $\begin{array}{l}\text { Bahasa yang digunakan dalam modul pembelajaran Nahwu sangat lugas dan } \\
\text { komunikatif. }\end{array}$ & $43 \%$ \\
\hline 5 & $\begin{array}{l}\text { Bahasa yang digunakan dalam modul pembelajaran Nahwu sangat dialogis dan } \\
\text { interaktif. }\end{array}$ & $22 \%$ \\
\hline 6 & Bentuk ilustrasi modul pembelajaran nahwu berbasis saintifik kelas sangat menarik & $62 \%$ \\
\hline 7 & Tampilan atau cover modul pembelajaran Nahwu berbasis saintifik sangat menarik. & $43 \%$ \\
\hline 8 & Modul pembelajaran Nahwu berbasis saintifik bias meningkatkan daya nalar siswa. & $60 \%$ \\
\hline 9 & Modul pembelajaran Nahwu berbasis saintifik berisi materi yang bersifat aplikatif. & $64 \%$ \\
\hline 10 & $\begin{array}{l}\text { Modul pembelajaran Nahwu berbasis saintifik sangat efisien dan efektif dalam } \\
\text { meningkatkan kualitas pembelajaran Nahwu. }\end{array}$ & $43 \%$ \\
\hline 11 & Modul pembelajaran Nahwu berbasis saintifik disusun secara sistematis dan aplikatif. & $64 \%$ \\
\hline 12 & $\begin{array}{l}\text { Modul pembelajaran Nahwu berbasis saintifik dapat mengaktifkan peserta didik dalam } \\
\text { proses kegiatan pembelajaran. }\end{array}$ & $42 \%$ \\
\hline
\end{tabular}




\begin{tabular}{|c|l|c|}
\hline 13 & $\begin{array}{l}\text { Modul pembelajaran Nahwu berbasis saintifik mampu meningkatkan perkembangan } \\
\text { intelektual dalam kehidupan di pesantren. }\end{array}$ & $43 \%$ \\
\hline 14 & $\begin{array}{l}\text { Modul pembelajaran Nahwu berbasis saintifik dapat meningkatkan sikap yang santun. } \\
\text { Modul pembelajaran Nahwu berbasis saintifik mampu meningkatkan sosialisasi antar } \\
15\end{array}$ & $40 \%$ \\
\hline 16 & Modul disusun sesuai dengan tingkat perkembangan peserta didik. & $42 \%$ \\
\hline 17 & Modul disusun dengan memperhatikan keruntutan dan keterpaduan alur piker & $59 \%$ \\
\hline 18 & Penggunaan istilah dan simbol dalam modul pembelajaran Nahwu sangat menarik & $63 \%$ \\
\hline 19 & Materi dalam modul pembelajaran Nahwu bebabasis saintifik sangat mudah dipahami. & $63 \%$ \\
\hline 20 & $\begin{array}{l}\text { Teknik Penyajian modul pembelajaran Nahwu bebasis saintifik didukung dengan } \\
\text { contoh-contoh yang mudah dipahami. }\end{array}$ & $83 \%$ \\
\hline
\end{tabular}

Dari tabel tersebut dapat disimpulkan bahwa untuk prosentase di atas $60 \%$ tergolong sebagai kelebihan dari modul pembelajaran sedangkan yang kurang dari $60 \%$ digolongkan sebagai kekurangannya. Kelebihan modul Pembelajaran Nahwu dengan menggunakan pendekatan saintifik ada 10 poin. (1) Pembelajaran Nahwu menggunakan modul berbasis saintifik dapat memudahkan siswa dalam belajar; (2) Pembelajaran Nahwu dengan menggunakan modul berbasis saintifik dapat meningkatkan motivasi siswa dalam mempelajari ilmu Nahwu. (3) Pembelajaran Nahwu dengan menggunakan modul berbasis saintifik dapat meningkatkan kemandirian siswa dalam mempelajari ilmu Nahwu; (4) Bentuk ilustrasi modul pembelajaran nahwu berbasis saintifik sangat menarik; (5) Modul pembelajaran Nahwu berbasis saintifik bisa meningkatkan daya nalar siswa; (6) Modul pembelajaran Nahwu berbasis saintifik berisi materi yang bersifat aplikatif; (7) Modul pembelajaran Nahwu berbasis saintifik disusun secara sistematis dan aplikatif; (8) Penggunaan istilah dan simbol dalam modul pembelajaran Nahwu sangat menarik; (9) Materi dalam modul pembelajaran Nahwu bebabasis saintifik sangat mudah dipahami; (10) Teknik Penyajian modul pembelajaran Nahwu bebasis saintifik didukung dengan contoh-contoh yang mudah dipahami.

Kekurangan modul Pembelajaran Nahwu dengan menggunakan pendekatan saintifik ada 9 poin. Bahasa yang digunakan dalam modul pembelajaran Nahwu kurang lugas dan kurang komunikatif. (1) Bahasa yang digunakan dalam modul pembelajaran Nahwu kurang dialogis dan interaktif; (2) Tampilan atau cover modul pembelajaran Nahwu berbasis saintifik kurang menarik; (3) Modul pembelajaran Nahwu berbasis saintifik sangat efisien dan efektif dalam meningkatkan kualitas pembelajaran Nahwu; (4) Modul pembelajaran Nahwu berbasis saintifik dapat mengaktifkan peserta didik dalam proses kegiatan pembelajaran; (5)Modul pembelajaran 
Nahwu berbasis saintifik kurang mampu meningkatkan perkembangan intelektual dalam kehidupan di pesantren; (6)Modul pembelajaran Nahwu berbasis saintifik kurang dapat meningkatkan sikap yang santun; (7)Modul disusun dengan tidak memperhatikan keruntutan dan keterpaduan alur piker; (8) Modul pembelajaran Nahwu berbasis saintifik kurang mampu meningkatkan sosialisasi antar peserta didik; (9) Modul belum disusun sesuai dengan tingkat perkembangan peserta didik.

\section{Kesimpulan}

Penelitian ini menyimpulkan beberapa poin. Efektifitas penggunaan modul pembelajaran nahwu dengan menggunakan pendekatan saintifik di SMA Darul Ulum 3 Jombang diukur dengan uji normalitas menggunakan uji Kolmogorov-Smirnov dalam aplikasi IBM SPSS Statistic 21 yang secara rinci telah disajikan dalam Tabel 4.5. Berdasarkan Tabel 4.5 didapatkan data prates nilai Sig. sampel untuk kelas kontrol sebesar 0,200 dan eksperimen sebesar 0,163 sehingga data kedua kelas sampel terdistribusi normal. Kelebihan dan kekurangan modul pembelajaran nahwu dengan menggunakan pendekatan saintifik di SMA Darul Ulum 3 Jombang berdasarkan saran atau komentar dari validator dan angket yang diisi oleh siswa pada kelas eksperimen dan kelas control. Adapun kelebihan modul berdasarkan saran atau komentar dari validator meliputi : 1) secara umum modul pembelajaran nahwu bagus dan mempermudah siswa, 2) pembelajaran siswa lebih efektif, dari teori langsung bisa aplikasi ke latihan soal, 3) meningkatkan motivasi siswa untuk belajar secara mandiri, 4) pembelajaran lebih menarik karena bersifat aplikatif ke dalam pembelajaran baca kitab kuning, 4) ilustrasi yang disajikan dalam modul bisa mengubah image bahwa pelajaran Nahwu yang sulit berubah menjadi mudah. 


\section{Referensi}

Alfat, Ibnu Wahid . 2011. Reaktualisasi Fan Nahwu .Bandung: Genesa product.

Anwar, Ilham. 2010. Pengembangan Bahan Ajar. Bandung: Direktori UPI.

Arikunto, Suharsimi. 2006. Prosedur Penelitian, Suatu Pendekatan Praktik. Jakarta: Rineka Cipta.

Amin, H. A. (2021). GUARDIANS CONCEPT IN QUR'AN PERSPECTIVE . SHAKHSIYAH BURHANIYAH: Jurnal Penelitian Hukum Islam,6(1), $95 \quad$ - 114. https://doi.org/10.33752/sbjphi.v6i1.1642

Al Amin, H. (2016). Tafsir Sufi Lataâ€TM if al-Isyarat. SUHUF, 9(1), 59-77.

Hobri. 2010. MetodologiPenelitianPengembangan.Jember: Pena Salsabila.

Hosnan, M. 2016. PendekatanSaintifikdanKontekstualdalamPembelajaran Abad 21. Bogor: Ghalia Indonesia.

Made, Wena. 2012. Strategi Pembelajaran Inovatif Kontemporer: Suatu Tinjauan Konseptual Operasional.Malang:Bumi Aksara.

Majid, A dan Rochman, C. 2015.PendekatanIlmiahdalamImplementasiKurikulum 2013. Bandung: PT RemajaRosdakarya.

Mulyasa,E. 2006. Kurikulum Berbasis Kompetensi: Konsep, Karakteristik, dan Implementasi. Bandug:Remaja Rosdakarya.

Mulyatiningsih,Endang. 2014. Metode Penelitian Terapan Bidang Pendidikan. Bandung: Alfabeta.

Mulyono. 2012. StrategiPembelajaran. Malang: UIN Maliki Press. 